\title{
鉄系焼結体の諸性質に及ぼす $\mathrm{Si}$ 添加の影響についで
}

\author{
柴田治 郎**.田辺重 則**
}

Jiro Shibata and Shigenori Tanabe: The Effects of Silicon on Mechanical Properties of Sintered Iron Compacts.

In order to investigate the effect of silicon on the mechanical properties of sintered iron compacts, $1 \sim 4 \% \mathrm{Si}$ were added to iron compacts, and $\mathrm{W}$ and Mo were also added to Fe-3\% Si compacts, which showed the improved mechanical properties. They were compacted and sintered by the single-press and sinter techniques, by the double-press and sinter techniques and studied of various mechanical properties. The results were summarized as follows.

(1) Generally, the addition of $\mathrm{Si}$ to iron compacts increased the hardness and the tensile strength, however decreased the elongation of the compacts sintered at $1120^{\circ} \mathrm{C}$.

(2) In the case of sintering at 1220 and $1300^{\circ} \mathrm{C}$, their densification was remarkably accelerated above $2 \% \mathrm{Si}$, and therefore gave not only a high tensile strength, but also a high clongation. But the elongation decreased at $4 \% \mathrm{Si}$.

(3) The sintered Fe-3\% Si compacts, when $\mathrm{W}$ and Mo were added, showed the improved mechanical properties. The elongation, however, decreased above $7 \% \mathrm{~W}$ and $5 \% \mathrm{Mo}$ because of the precipitation of the compounds, namely $\mathrm{Fe}_{2} \mathrm{~W}$ and $\mathrm{Fe}_{2} \mathrm{Mo}$.

(4) The double-press and sinter techniques generally gave higher strengths than the single-press and sinter techniques, although at high temperatures there were only slight differences between both techniques.

(Received January 24, 1972)

\section{I 緒 言}

近年，鉄系焼結機械部品の需要が増大するにつれて，


相焼結， C，Ni，Mnなどの添加による合金效果扰よび こ机らの焼結体に熱処理を施すことによって，功なり高 強度の焼結体が得られている. しかし, 同程度の強度を 有する溶解鍛造材に比較して伸び，衝撃值が著しく劣つ ており，ての対策としてNi の多量添加, Hot Press 法および烧結鍛造法などが検討され大きな效果をあげて いるが，適当な強欨性をあった狫結体を得るには，これ らの方法では経斉性，量産性の点で問題がある．したが って，適当な添加元菜を用いて普通焼結法でかなりの強 靱材が得られれば，この方が有利な場合も多い上考えら れる。

$\mathrm{Si}$ は Fe のフェライト地の強さ，硬さを高兴用 が強く, 耐食性, 耐酸化性を高わる元薪であり,また焼結 中に执いて $\mathrm{Fe}$ 中への拡散が景く”， $\mathrm{Fe}$-Si 状態図 ${ }^{22}$
では $1200^{\circ} \mathrm{C}$ で $\mathrm{Fe}-20 \% \mathrm{Si}$ の組成で共暃反応があり， この湿度以上に抢いては液相が発生して焼結を促進させ ることも予想され， Fe 煃結体の添加元素としては非常 に有効であると考えられる。しかし， $\mathrm{Fe}$ 粉への $\mathrm{Si} の$

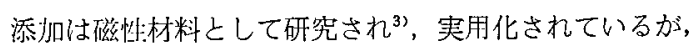
機械部品としての研労は少ないので, Si の添加量, 焼 結温度，再压縮・再焼結が鉄系焼結体の密度，硬さ，抗 張力，伸びおよご顕微鏡組織にどのような影響を与える 加を調查し, さらに C, Cu, $\mathrm{Ni}, \mathrm{Mn}, \mathrm{Co}, \mathrm{Cr}, \mathrm{W}$, Mo などの第 3 元素の影響についてす比較検討した.

\section{川 使用粉末および実験方法}

\section{I-1 使用粉末}

$\mathrm{Fe}$ 粉はへガネスの鉣石還元鉄粉 (MH 100.28), Si 粉 末は純度 $98 \%$ 以上の金属ケイ素を粉䂶したのち，塩酸で

* 昭和 46 年 5 月 本協会春季大会 (東京) 飞て発表

** 大阪府立大学工学部金属工学科 堺市百舌鳥梅町 4 丁 




Fig. 1 Specimen for tensile test.

鉄分を除去した平均粒度 $1.5 \mu$ の粉末を使用した。 C, $\mathrm{Cu}$ ， $\mathrm{Ni}, \mathrm{Mn}, \mathrm{Co}, \mathrm{Cr}, \mathrm{W}, \mathrm{Mo}$ 粉末の平均垃度はそ机ぞれ 2.1 $6.2,4.0,5.0,1.5,25.4,0.8,4.3 \mu$ である.

\section{II -2 実験方法}

$\mathrm{Fe}$ 粉に Si 粉末を 1 ～496添加し，さらに第 3 元菜 として Cu, Ni, Mn, Co, Cr, W, Mo は2 3\%, C は 0.2 および $0.6 \%$ 添加し，ステアリン酸互鉊を 0.75 $\%$ 加えてボールミルで $2 \mathrm{hr}$ 混合した. 圧粉成形は $6 \mathrm{t} /$ $\mathrm{cm}^{2}$ で Fig. 1 亿示す形状に成形し，焼結は $10^{-1} \sim 10^{-2}$ $\mathrm{mmHg}$ の真空中, 1120,1220 および $1300^{\circ} \mathrm{C}$ で $1 \mathrm{hr}$ 行 なった．また，再圧縮・再䡒結は上記の圧粉体を $800^{\circ} \mathrm{C}$ $\times 30 \mathrm{~min}$ 予備焼結後, $6 \mathrm{t} / \mathrm{cm}^{2}$ で再圧縮して 1120,1220 および $1300^{\circ} \mathrm{C} て ゙ ~ 1 \mathrm{hr}$ 焼結した，燒結体の収縮率（試 験片の長さ方向), 密度 (浸漬法による溶解材との相対 密度值\%), 硬さ(ロックウェル硬さ), 抗張力, 伸び(標 点間距離 $25 \mathrm{~mm}$ ) を測定し，顕微鏡組織はナイタールで 腐食して観察した。また X線回折 $\left(\mathrm{CoK}_{\alpha}\right)$ で析出物の 同定を行なった。

\section{IIII実験結果および考察}

III-1 Fe 焼結体の性質に及ぼす $\mathrm{Si}$ 添加の影響

1〜4\%の Si を添加した Fe-Si 圧粉体の熱膨張曲 線老求めると， $1 \% \mathrm{Si}-\mathrm{Fe}$ では $1200^{\circ} \mathrm{C}$ 付近より収縮し はじぬるが $1300^{\circ} \mathrm{C}$ で $1 \mathrm{hr}$ 保持してあ収縮量は少ない， しかし，2 4\% Si-Fe では 1000 1050 $0^{\circ} \mathrm{C}$ 上り急激に収 縮しはじめて $1300^{\circ} \mathrm{C}$ まで続き, $1300^{\circ} \mathrm{C}$ の保持中は初 期においては収縮が残るが，その後期はほとんど収縮し なくなることがわかったので，焼結温度として普通用い られている $1120^{\circ} \mathrm{C}, \mathrm{Fe}-\mathrm{Si}$ の共鼠温度の直上の $1220^{\circ} \mathrm{C}$ およびはとんど完全に燒結する $1300^{\circ} \mathrm{C} の 3$ 種類を選ん だ. $1120^{\circ} \mathrm{C}$ で普通焼結およご再圧縮・再烍結した場合 の Fe-Si 焼結体の性質を Fig. 2 亿示す. 乙の焼結温 度では $1 \% \mathrm{Si}-\mathrm{Fe}$ はほとんど収維しない.2\%以上の $\mathrm{Si}$ 添加では順次収縮量む大きくなるが, Si 添加によっ て压粉性が悪くなり，压粉体の密度が低くなるために密 度はあまり変化しない。

Si はフェライトを強化する作用が強く ${ }^{52}$, 固溶強化は 大きいので Si の添加量が多くなるにつれて硬さ，抗張 力は増大し，伸びは減少する，再正縮・再佬結に扔いて は，再圧縮により予借焼結体の密度が上昇するので普通

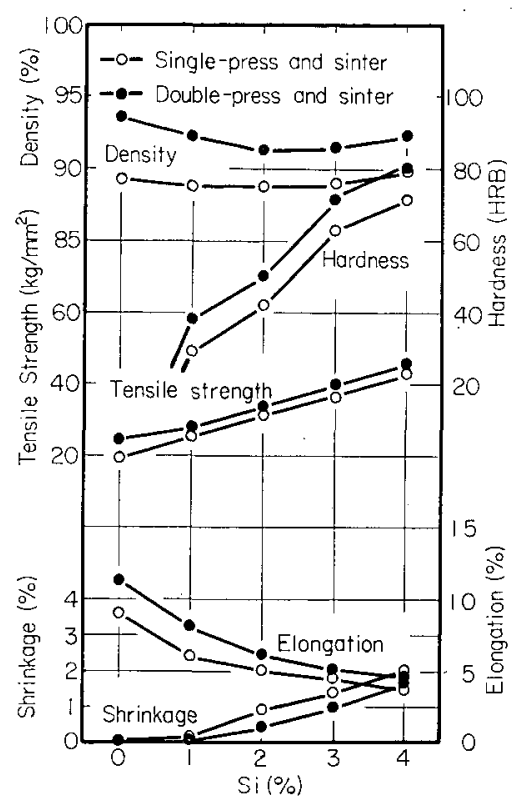

Fig. 2 The effect of silicon on various proper. ties of iron compacts sintered at $1120^{\circ} \mathrm{C}$ for $1 \mathrm{hr}$.

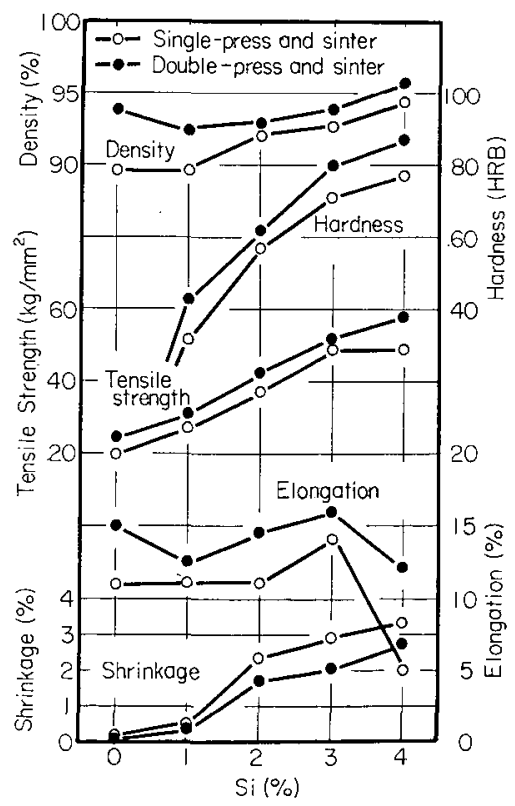

Fig. 3 The effect of silicon on various properties of iron compacts sintered at $1220^{\circ} \mathrm{C}$ for $1 \mathrm{hr}$.

焼結に比較して収縮量は少なくなるが，焼結体の密度， 硬さ，抗張力拉よび伸びは上昇する。

$1220^{\circ} \mathrm{C}$ で燒結した Fe-Si 焼結体の性質を Fig. 3 亿 示す.

$\mathrm{Fe}-\mathrm{Si}$ は $1200^{\circ} \mathrm{C}$ 亿共晶温度があり, $1220^{\circ} \mathrm{C}$ の焼結 
では液相が一部発生し, 焼結が促進されることが予想さ れる.

$1 \% \mathrm{Si}-\mathrm{Fe}$ では Fe 単味とほとんど変わらないが, $2 \% \mathrm{Si}$ 以上の添加では収縮量が大きくなり, 緻密化に伴 って密度, 硬さ, 抗張力, 伸びは $1120^{\circ} \mathrm{C}$ の焼結に比較 して上昇する.

Si はフェライト地を強化するが脆化を伴うので, $1220^{\circ} \mathrm{C}$ の燒結において $\mathrm{Si}$ の添加によって伸びが上昇 するととに疑問があるが，焼結体の強勒性は気孔による 切欠き効果によって大きく左右されるので, 焼結温度の 上昇による密度の増加と, それに伴う粒子間の結合力の 増加抢よび気孔の球状化によって強化されるとともに伸 びあ改善されるあのと考えられる。しかし，伸びは $3 \%$ $\mathrm{Si}$ で最大値を経て，4\% $\mathrm{Si}$ ではフェライトの脆化によ り急激仁低下し，脆性破面を呈する．再圧縮・再焼結で は密度が増加するととすに諸性質は向上し，とくに伸び の增加は著しい．

$1300^{\circ} \mathrm{C}$ で焼結した Fe-Si 焼結体の性質を Fig. 4 亿 示す. 収縮量, 硬さ, 抗張力は $1220^{\circ} \mathrm{C}$ で焼結した場合 とほとんど変わらないが，密度は $2 \% \mathrm{Si}$ 以上で高くな り，伸びあ全般に良くなり，とくに 2 3\% Si で著しい 上昇が認められる。再圧縮・再焼結は焼結体の諸性質を 向上させるが，その効果は低温度の燒結に比較して少な い.

$3 \% \mathrm{Si}-\mathrm{Fe}$ 焼結体の燒結温度による顕微鏡組織の変化 を Photo. 1 に示す. $1120^{\circ} \mathrm{C}$ の焼結では焼結温度が低 いために多数の気孔が残存し, 粒成長も少ないが, 焼結



Fig. 4 The effect of silicon on various properties of iron compacts sintered at $1300^{\circ} \mathrm{C}$ for $1 \mathrm{hr}$.



$1120^{\circ} \mathrm{C}$

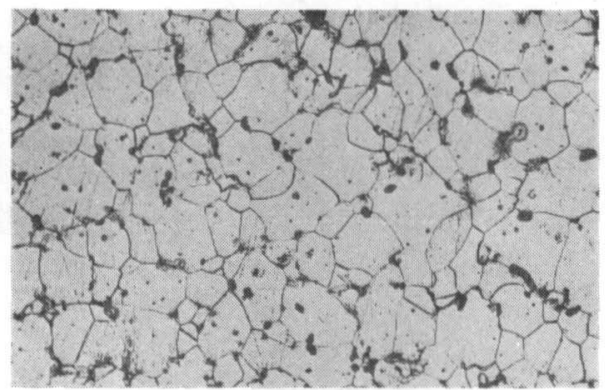

$1200^{\circ} \mathrm{C}$

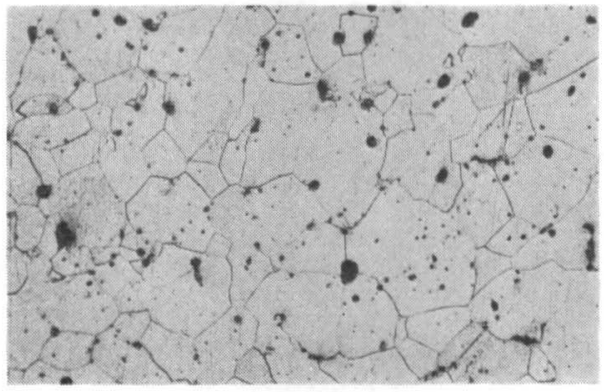

$1300^{\circ} \mathrm{C}$

Photo. 1 Microstructures of iron-3\% silicon compacts sintered at 1120,1220 and $1300^{\circ} \mathrm{C}$ for $1 \mathrm{hr} .(\times 100)$

温度が $1220,1300^{\circ} \mathrm{C}$ と高くなるにつれて燒結が進み, 気孔が少なく球状化するととあに粒成長が起とる. また， 普通焼結と再圧縮・再焼結とでは顕微鏡組織に大きな差 異は認めら机なかった。

$1220^{\circ} \mathrm{C}$ で焼結した $\mathrm{Fe}-\mathrm{Si}$ 焼結体の顕微鏡組織を Photo. 2 に示す. Si の添加量が多くなるにつれて, 微 細な気孔は少なくなり，大きな気孔あ球状化する．乙れ が燒結体の伸びを上昇させる原因と考えられる．1\% Si では結晶粒の粗大化が認められるが, 2 4\% Si では粒 成長が抑制され，1\% $\mathrm{Si}-\mathrm{Fe}$ 亿比較して結晶粒は細かく なる. 田村ら ${ }^{6)}$ は $\mathrm{Fe}-\mathrm{W}$ の焼結において, 5\%W では 結晶粒は微細であるが，8\%W では粗粒になるととを認 め, 焼結中において, 完全に合金化が完了したとすれば, $8 \% \mathrm{~W}-\mathrm{Fe}$ では $\alpha$ 相のみであるが, $5 \% \mathrm{~W}-\mathrm{Fe}$ では $\alpha+\gamma$ の二相であるために粒成長が起とりにくいと説明してい る. $\mathrm{Fe}-\mathrm{Si}$ の場合む $\mathrm{Fe}-\mathrm{W}$ と同様に状態図上の $\gamma$ 領域 


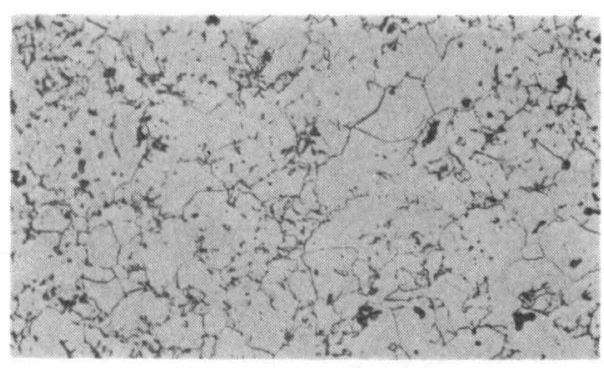

$\mathrm{Fe}$

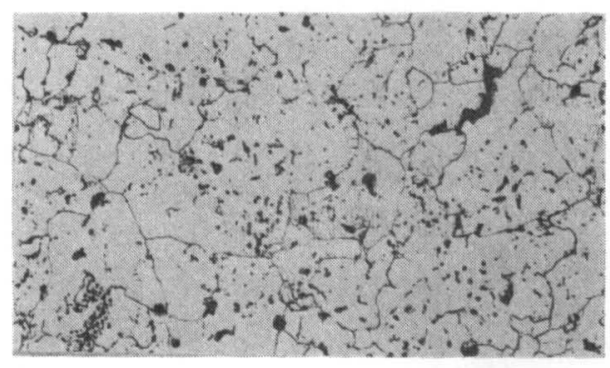

$\mathrm{Fe}-1 \% \mathrm{Si}$

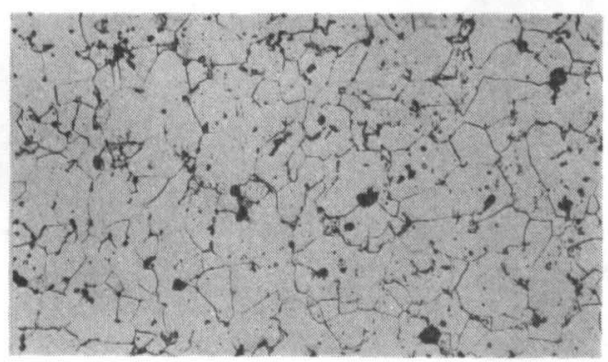

$\mathrm{Fe}-2 \% \mathrm{Si}$

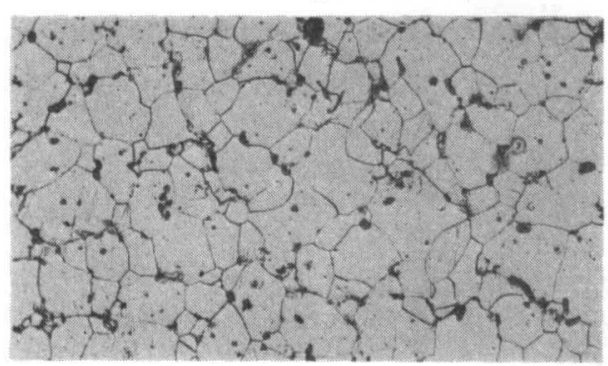

$\mathrm{Fe}-396 \mathrm{Si}$

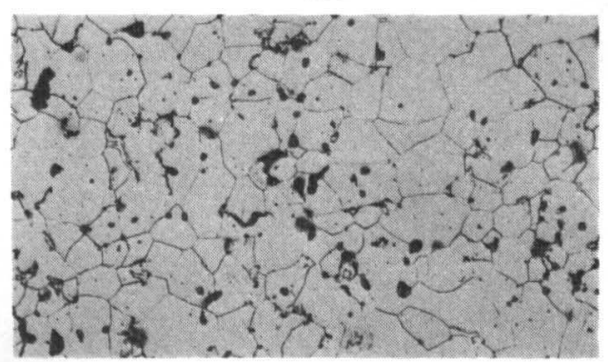

$\mathrm{Fe}-496 \mathrm{Si}$

Photo. 2 Microstructures of iron-silicon compacts sintered at $1220^{\circ} \mathrm{C}$ for $1 \mathrm{hr}$. $(\times 100)$
を三力月形にするので, 焼結中においては当然 $\alpha+\gamma$ の 二相が存在し，2 4\% Si では粒成長が抑制されるもの と考えられる.

$1220,1300^{\circ} \mathrm{C}$ の焼結において, Si を $2 \%$ 以上添加し た場合, 収縮量が大きくなり, 焼結体の性質が向上した ので, このような焼結温度においては液相が一部発生す るのではないかと考えた. しかし, 気孔の減少および球 状化は認められたが, この焼結温度で液相が発生したか どうかは影微鏡組織からは確認できなかった。

III-2 $\mathrm{Fe}-3 \% \mathrm{Si}$ 焼結体の性質に及ぽす第 3 元素の影響

$\mathrm{Fe}$ 粉に数\%の $\mathrm{Si}$ 粉末を添加して焼結すると, $\mathrm{Fe}$ 焼 結体の機械的性質が向上し, とくに $1220^{\circ} \mathrm{C}$ 以上の焼結 温度では伸びの上昇が著しいととがわかったので, 最む 強勒な $3 \% \mathrm{Si}-\mathrm{Fe}$ について, さらに C, $\mathrm{Cu}, \mathrm{Ni}, \mathrm{Mn}$, $\mathrm{Co}, \mathrm{Cr}, \mathrm{W}, \mathrm{Mo}$ 粉末を添加し, 焼結体の諸性質がどの ように変化するかを検討した，その結果を Table 1 に 示す. C, $\mathrm{Cu}$ は焼結体の密度を低下させるとともに $\mathrm{Fe}$ 地を硬化させるために伸びは著しく低下する． $\mathrm{Ni}, \mathrm{Mn}$, $\mathrm{Co}, \mathrm{Cr}$ は $\mathrm{C}, \mathrm{Cu}$ のように顕著な影響はないが, 密度, 硬さ, 抗張力, 伸びなどの性質は $\mathrm{Fe}-3 \% \mathrm{Si}$ 焼結体より あ低くなり，性質の改善は認められなかった。しかし， W, Mo は抗張力, 伸びを改善し, Fe-3\% Si 焼結体の 添加元素として有効であるととがわかったので，その添 加量の影響について検討した.

III-3 Fe-3\%Si 燒結体の性質に及ぼす W, Mo の影 響

$\mathrm{Fe}-3 \% \mathrm{Si}$ にW粉末を1 10\%添加し， 1220 および $1300^{\circ} \mathrm{C}$ で $1 \mathrm{hr}$ 焼結した場合の焼結体の性質を Fig. 5 および Fig. 6 に示す. Wの添加は Fe-3\%Si 焼結体の 性質を向上させるが, $1220^{\circ} \mathrm{C}$ の焼結では抗張力は $10 \%$ $\mathrm{W}$ で低下し, 伸びは $5 \% \mathrm{~W}$ 以上で著しく低下する. $1300^{\circ} \mathrm{C}$ の焼結では $1220^{\circ} \mathrm{C}$ の燒結に比較して収縮量, 密度は大きくなり, それに伴って諸性質は向上し, 伸び の最高値は $1 \% \mathrm{~W} て ゙$ て現われる. 再圧縮・再燒結は性質を 改善するが, $1300^{\circ} \mathrm{C}$ の場合は $1220^{\circ} \mathrm{C}$ に比較して, そ の効果は少なく, またW量による諸性質の変化の傾向は 普通燒結の場合之ほ上んど変わらない。

$1220^{\circ} \mathrm{C}$ で焼結した $\mathrm{Fe}-3 \% \mathrm{Si}-\mathrm{W}$ 焼結体の顕微鏡組 織を Photo. 3 に示す. $3 \% \mathrm{~W}$ までは $\mathrm{Fe}$ 中に固溶され て $\alpha$ 相のみとなるが， $5 \% \mathrm{~W}$ では粒界に 化合物が析出 し, さらにW量が増加すると, 化合物の量が多くなると とあに結晶粒内にあ化合物が析出してくる. この化合物 が焼結体の伸びを著しく阻害するあのと考えられる。

$\mathrm{Fe}-3 \% \mathrm{Si}$ に Mo 粉末を1 5 \% 添加し, 1220 および $1300^{\circ} \mathrm{C}$ で $1 \mathrm{hr}$ 焼結した場合の焼結体の性質を Fig. 7 に示す. Mo の添加はW添加の場合と同様に $\mathrm{Fe}-3 \% \mathrm{Si}$ 
Table 1 The effect of the third element on various properties of iron$3 \% 6$ silicon compacts sintered at $1300^{\circ} \mathrm{C}$ for $1 \mathrm{hr}$.

\begin{tabular}{|c|c|c|c|c|}
\hline Component & $\begin{array}{l}\text { Density } \\
\left(\mathrm{g} / \mathrm{cm}^{3}\right)\end{array}$ & $\begin{array}{l}\text { Tensile strength } \\
\left(\mathrm{kg} / \mathrm{mm}^{2}\right)\end{array}$ & $\begin{array}{c}\text { Elongation } \\
(\%)\end{array}$ & $\begin{array}{c}\text { Hardness } \\
\text { (HRB) }\end{array}$ \\
\hline $\mathrm{Fe}-396 \mathrm{Si}$ & 7.39 & 49 & 17 & 74 \\
\hline $\mathrm{Fe}-3 \% \mathrm{Si}-0.296 \mathrm{C}$ & 7.01 & 46 & 9 & 66 \\
\hline $\mathrm{Fe}-396 \mathrm{Si}-0.696 \mathrm{C}$ & 6.75 & 49 & 3 & 74 \\
\hline $\mathrm{Fe}-3 \not 6 \mathrm{Si}-2 \not 6 \mathrm{Cu}$ & 6.90 & 48 & 3 & 72 \\
\hline $\mathrm{Fe}-396 \mathrm{Si}-3 \not 6 \mathrm{Ni}$ & 7.10 & 46 & 9 & 69 \\
\hline $\mathrm{Fe}-396 \mathrm{Si}-396 \mathrm{Mn}$ & 7.07 & 45 & 9 & 68 \\
\hline $\mathrm{Fe}-3 \not 6 \mathrm{Si}-296 \mathrm{Co}$ & 7.14 & 46 & 13 & 69 \\
\hline $\mathrm{Fe}-396 \mathrm{Si}-296 \mathrm{Cr}$ & 7.12 & 44 & 13 & 67 \\
\hline $\mathrm{Fe}-396 \mathrm{Si}-3 \% \mathrm{~W}$ & 7.55 & 57 & 19 & 89 \\
\hline $\mathrm{Fe}-3 \% 6 \mathrm{Si}-3 \% \% \mathrm{Mo}$ & 7.47 & 55 & 19 & 86 \\
\hline
\end{tabular}

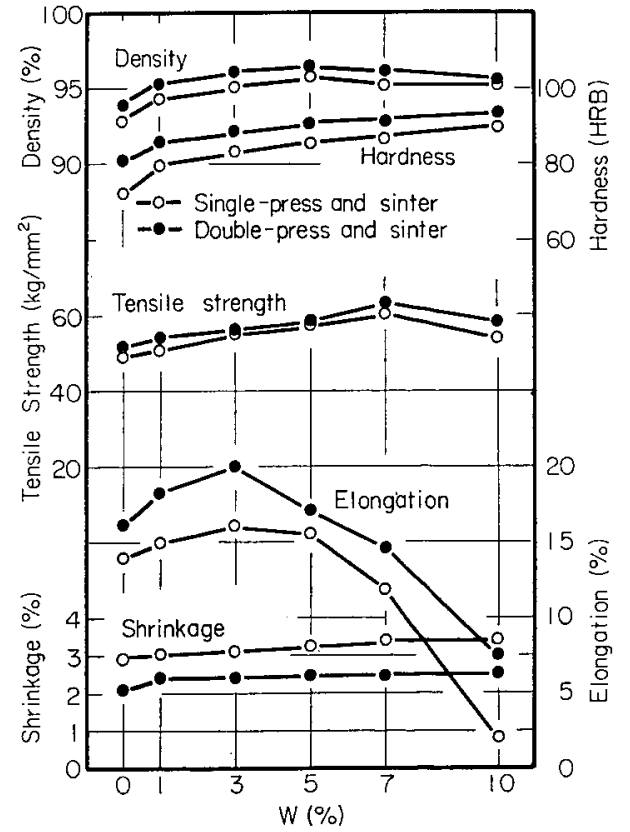

Fig. 5 The effect of tungsten on various properties of iron-3\%silicon compacts sintered at $1220^{\circ} \mathrm{C}$ for $1 \mathrm{hr}$.



Fig. 6 The effect of tungsten on various properties of iron-3\% silicon compacts sintered at $1300^{\circ} \mathrm{C}$ for $1 \mathrm{hr}$. 


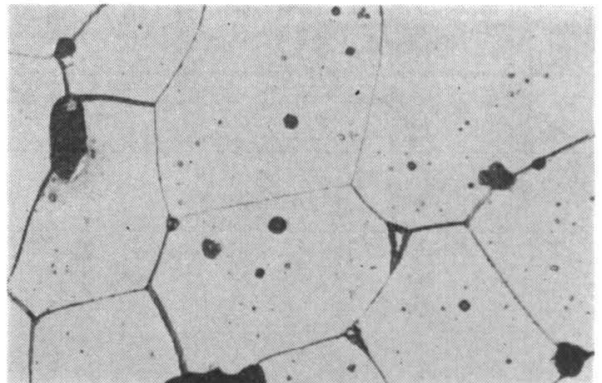

$\mathrm{Fe}-3 \% \mathrm{Si}-3 \% \mathrm{~W}$

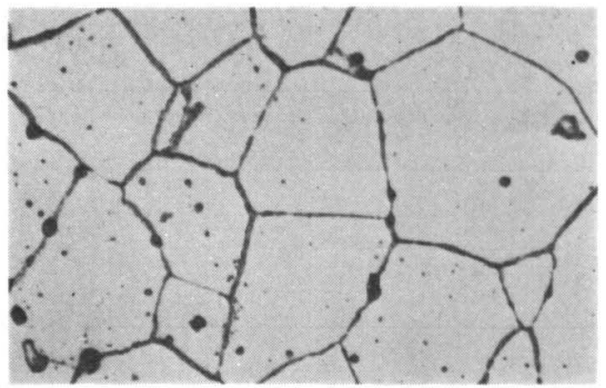

$\mathrm{Fe}-3 \% \mathrm{Si}-5 \% 6 \mathrm{~W}$

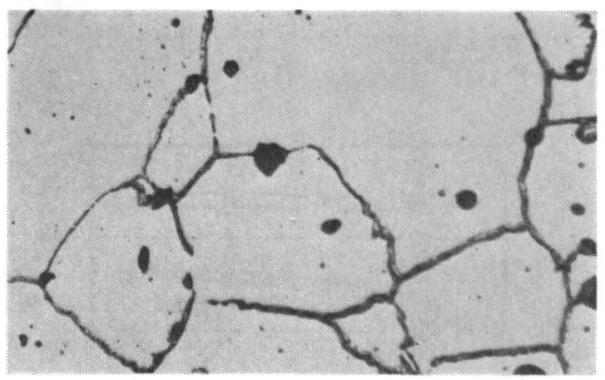

$\mathrm{Fe}-3 \% \mathrm{Si}-7 \% \mathrm{~W}$

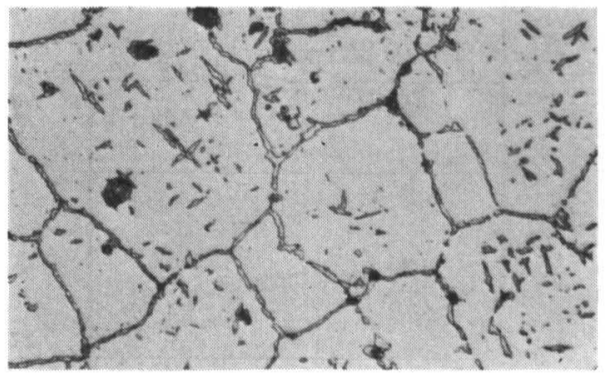

$\mathrm{Fe}-3 \% \mathrm{Si}-10 \% \mathrm{~W}$

Photo. 3 Microstructures of iron-3\% silicontungsten compacts sintered at $1220^{\circ} \mathrm{C}$ for $1 \mathrm{hr} .(\times 400)$

焼結体の性質を向上させるが，その効果はWに比較して わずかに少ない，伸びは $1220^{\circ} \mathrm{C}$ の焼結では $1 \% \mathrm{Mo}$ で 極大值を示し，Mo の添加量肪増加するにつれて低下す るが, $1300^{\circ} \mathrm{C}$ では $3 \% \mathrm{Mo}$ まで渐増し，5\% Mo で急激 に低下する。

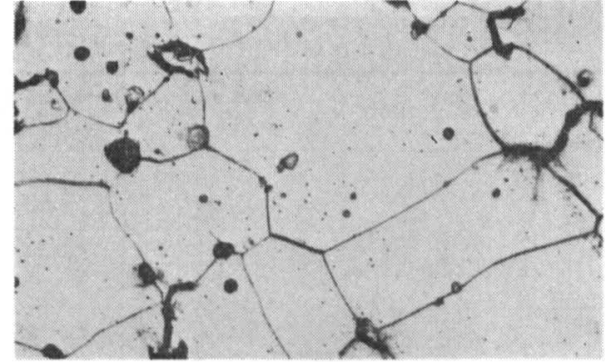

Fe-396Si-196Mo

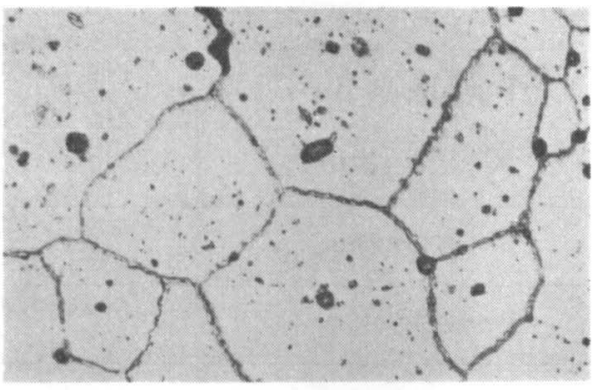

$\mathrm{Fe}-3 \% \mathrm{Si}-3 \% \mathrm{Mo}$

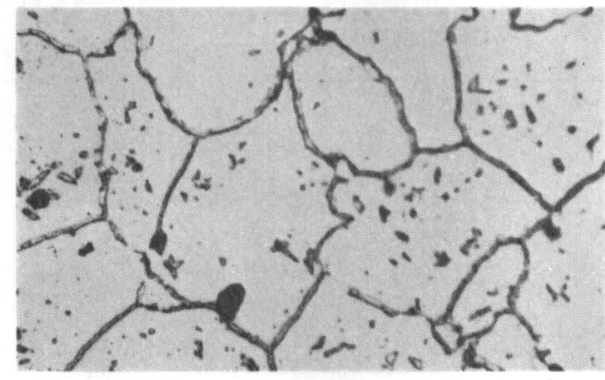

$\mathrm{Fe}-396 \mathrm{Si}-506 \mathrm{Mo}$

Photo. 4 Microstructures of iron-3\%siliconmolybdenum compacts sintered at $1220^{\circ} \mathrm{C}$ for $1 \mathrm{hr} .(\times 400)$

$1220^{\circ} \mathrm{C}$ で焼結した $\mathrm{Fe}-3 \% \mathrm{Si}-\mathrm{Mo}$ 燒結体の顕微鏡組 織をPhoto. 4 に示す. 3\% Mo では化合物がわずかに 粒界に析出するが， 5\% Mo ではその量が多くなり，粒 内にも析出してくる. このように化合物の析出が焼結体 の伸びを低下させるのはWの場合と同様である.

Wおよび Mo を添加した場合に析出する化合物は X 線回折によると, $\mathrm{Fe}_{2} \mathrm{~W}$ および $\mathrm{Fe}_{2} \mathrm{Mo}$ である.

\section{IV 結 論}

$\mathrm{Fe}$ 焼結体の性質に及ぽす $\mathrm{Si}$ 添加の影響を普通焼結 法および再圧縮・再焼結法について検討し, さらに Fe3\% Si にWおよび Mo を添加した場合について調べた 結果, 次のととがわかった。

(1) $\mathrm{Si}$ の添加は $\mathrm{Fe}$ 焼結体の硬さ, 抗張力を增加さ せるが $1120^{\circ} \mathrm{C}$ の焼結では勒性を低下させる.

（2） 1220 および $1300^{\circ} \mathrm{C}$ の焼結においては $2 \% \mathrm{Si}$ 以 


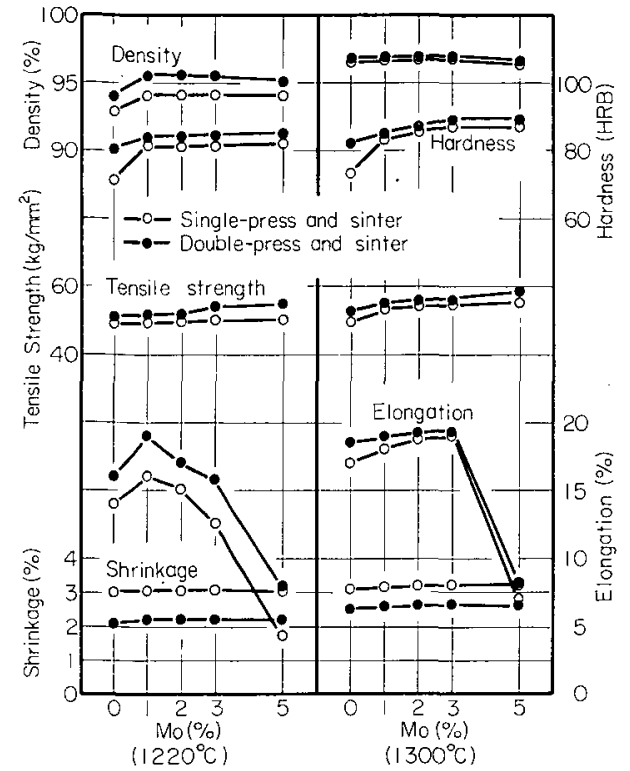

Fig. 7 The effect of molybdenum on various properties of iron-3\%silicon compacts sintered at 1220 and $1300^{\circ} \mathrm{C}$ for $1 \mathrm{hr}$.
上で密度は著しく上昇し，それに伴って硬さ，抗張力は 増大し，とくに伸びの增加落しいが，4\% 岻下する。

（3）W および Mo の添扣は Fe-3\% Si の硬さ，抗張 力，伸びを增加させるが，W $7 \%$ ，Mo は $5 \%$ で化合 物が析出するために伸びは低下する。

（4）再圧縮・再焼結は烧結体の性質を向上させるが， 高温燒結ではその効果は少なくなる。

\section{文献}

1) W.D. Jones: Fundamental Principles of Powder Metallurgy, Edward Arnold, London (1960), 452.

2) M. Hansen : Constitution of Binary Alloys, 2nd Ed.. McGraw-Hill, New York (1958), 713.

3) F.W. Glaser : Powder Met. Bull., 4(1949), 19.

4) L. Harrison and R.H. T. Dixon : Powder Met. 9 (1962), 247.

5）日本学術振興会編：鉄鋼と合金元素（上），誠文堂新光社 (1966), 5 .

6）田村, 村松：粉体粉末冶金協会春季大会講演慨要集（昭和 44), 2 .

\section{第 11 回 害業基礎討論会講演募 集}

日時 昭朴48年 1月25日（木），26日（金）

場 所 岡山県総合文化センター(成山市天神町8-54)

共 催 日本化学会, 同中国四国支部, 窞業協会, 同中国四国支部，粉体粉末冶金協会

主＼cjkstart題 (1) セラミックスの微棏造之物性

(2) 相変化一雾国気, 異種成分の影響

\section{講演およひ Short Comment の申込要領}

申込締切 9 月15日必着

時間 講演(講演時間20分, 討論10分)

Short Comment (1件 $5 \sim 10$ 分程度)

申込方法 㹃演または Short Comment の別, 主題 (1)または(2)を指定し, 題目, 発表者（講演 者○印)，勤務先，連絡先，それに内容の 概要 (約400字)をつけるとと，なお講演ま たは Short Comment の題目の英文と， 発表者のローマ字, 勤務先の英文をつけて 下さい.

\section{要旨締切 10 月 30 日}

探択された講演については原稿用紙および執筆要領を
お送りします，要旨は図表を含め，䑶演の場合は原稿 用紙 4 ペーシ (約6000字), Short Comment の場合 は 1 ページ(約 1500 字) です。な昖会場ではスライド に限定します。

\section{参加登録について}

参加登録費（講演要旨集 1 帆老含む）

$\begin{cases}\text { 予約の場合 } & 1600 \text { 円 (郵送料を含む) } \\ \text { 非予約の埸合 } & 2000 \text { 円 }\end{cases}$

予約された方にはあらかじめ蓝演要旨集を送付し ますので，できるだけ予約して下さい，

予約訷込締切 11月20日

○予約代金は締切日までに必ず現金畵留で送金下さい。 愁親会 1 月25日 夜, 会場未定

会 費 1 名 約2000円（会費は当日文払っていた だきます)

申込締切 11 月20日

申込先（詳細問合せ先）

干700 岡山市津島 岡山大学工学部

高橋克明（電話0862-52-1111 内線529） 